\title{
Nanotoxic Effects of Silver Nanoparticles on Normal HEK-293 Cells in Comparison to Cancerous HeLa Cell Line
}

This article was published in the following Dove Press journal: International Journal of Nanomedicine

\author{
Xiongwei Liu',* \\ Kuizhong Shan ${ }^{2, *}$ \\ Xiaxia Shao' \\ Xianqing Shi ${ }^{3}$ \\ Yun $\mathrm{He}^{4}$ \\ Zhen Liu' \\ Joe Antony Jacob (iD ${ }^{5}$ \\ Lichun Deng'
}

'Department of Oncology, Affiliated Jiangyin Hospital of Medical College, Southeast University, Jiangyin, People's Republic of China; ${ }^{2}$ Department of Oncology, The Second People's Hospital of Kunshan, Kunshan, People's Republic of China; ${ }^{3}$ Department of Oncology, Liyang People's Hospital, Liyang, People's Republic of China; ${ }^{4}$ Department of Oncology, Affiliated Hospital of Chinese University of Chinese Medicine, Changshu, People's Republic of China;

Consulting, Salem, Tamil Nadu, India

*These authors contributed equally to this work Medicine of Changshu City, Nanjing

${ }^{5}$ Nanosynthesis Unit, Nanome

\begin{abstract}
Purpose: Biomimetic approaches for the synthesis of silver nanoparticles (AgNPs) had created a substantial impression among the research community that focuses on nano-bio interactions. In this study, an eco-friendly method using Rhizophora apiculata aqueous leaf extract as a reductant-rich hydrosol was followed to synthesize AgNPs and test its cytotoxicity.
\end{abstract}

Methods: To optimise the parameters for the synthesis of AgNPs, central composite design based on response surface methodology was used. The particles synthesized at a nano-scale were characterized in our previously published report. The present report further characterizes the nanoparticles by X-ray diffraction, SEM and TEM at varying sites and magnifications. The characterized AgNPs were tested for their cytotoxic effects on HEK-293 and HeLa cells.

Results: The cytotoxicity on the cell lines was dose-dependent. At a concentration of 2.5 $\mu \mathrm{L} / \mathrm{mL}$ of the AgNPs-containing hydrosol, $100 \%$ inhibition of HEK-293 cells and $75 \%$ inhibition of the HeLa cells were observed. The $\mathrm{IC}_{50}$ value for AgNPs on HEK-293 was $0.622 \mu \mathrm{L} / \mathrm{mL}$ (12.135 ng), whereas, for HeLa cells, it was $1.98 \mu \mathrm{L} / \mathrm{mL}$ (38.629 ng).

Conclusion: The nanoparticles were three-fold toxic towards the HEK-293 cells in comparison to the HeLa cells. Therefore, the therapeutic index is low for R. apiculata derived AgNPs on HeLa cells when tested in comparison with the HEK-293 cells. The nanotoxicity profile of the synthesized AgNPs seems more prominent than the nanotherapeutic index. According to our knowledge, this is the first-ever report on the optimization of synthesis of AgNPs using response surface methodology and identifying the therapeutic index of mangrove leaf-derived AgNPs.

Keywords: AgNPs, XRD, HEK-293, HeLa, nanotoxicity

\section{Introduction}

Correspondence: Lichun Deng Department of Oncology, Affiliated Jiangyin Hospital of Medical College, Southeast University, No. 163 Shoushan Road, Jiangyin, 214400 , Jiangsu Province, People's Republic of China

Tel +86510 806I5131

Email18921233265@163.com

Joe Antony Jacob

Nanosynthesis Unit, Nanome Consulting,

No. II, Kannankurichi Road, Salem,

636008, Tamil Nadu, India

$\mathrm{Tel}+91-9443861940$

Email joeantonyjacob@gmail.com
Nanoparticles are usually synthesized using two approaches: top-down and bottomup. Physical methods break particles from bulk to fine forms by a top-down approach. Biological and chemical methods build particles from the bottom-up. The atoms self-assemble into nuclei which later lead to the formation of particles in the size of the nanometer via covalent or supramolecular contact. ${ }^{1,2}$ Green approaches for the synthesis of AgNPs using different sources such as plants are a blooming area of research because of their antioxidant and the resultant cytotoxic effects. ${ }^{3-5}$ Since plants are a rich source of secondary metabolites that can act as reductants and capping agents, the advantages of biological synthesis are 
numerous. ${ }^{6}$ The mechanism of nanoparticle synthesis using plants has been elucidated by several reports. The metal ions interact with the phytochemicals of the plant which eventually reduce the metal ions. The reduced ions nucleate and combine to form larger materials from tinysized ones by Ostwald ripening. Later, the particles integrate to form a definite and final shape. ${ }^{7}$

Although the advantages of nanomedicine appear plenty, risk assessment and analysis of the exposure of these particles obtained using rapid synthesis procedures towards normal or cancer cells are critical at specific doses for enhanced applications in nanomedicine. ${ }^{8,9}$ The toxicity assessment for health hazards of AgNPs is still in its infancy although their role in nanomedicine is well known. ${ }^{10-12}$ Few reports indicate both local and systemic toxicity of AgNPs, with mechanisms that relate to toxicity at genome levels, induction of immune cells, and oxidative stress. Various modes of exposure can lead to size, dose and encapsulation-dependent cellular uptake of AgNPs. Further enduring studies using several models can indicate the specific modes of toxicity. ${ }^{13-16}$

Human embryonic kidney 293 (HEK-293) cells are one among the widely used standards for normal human cells. It is believed to be derived from embryonic kidney cells using adenoviral DNA in the 1970s. ${ }^{17}$ Nanoparticles, especially nanosilver, are known to be toxic to HEK-293 and other cell lines which are considered to be normal. ${ }^{18-20}$ $\mathrm{HeLa}$ is the first immortalised human cervical adenocarcinoma cell line to be cultured in vitro in 1951 and stabilised in 1953 at Johns Hopkins Hospital in Baltimore, Maryland, US. It is a key cell line that revolutionised cancer research by accounting for more than sixteen thousand scientific publications related to oncology. ${ }^{21}$

MTT assay, which is a widely applied or standard method to elucidate the cytotoxic potential of agents at the preclinical level, was used to determine the dose related to cell death. ${ }^{22}$ In pharmacology, half-maximal inhibitory concentration $\left(\mathrm{IC}_{50}\right)$ is a determinant of how potent an antagonistic drug is. ${ }^{23}$ AgNPs are well known for their cytotoxicity on cancer cells, with a special mention to HeLa cells. ${ }^{24,25}$ Therefore, MTT assay was used in this study to determine the $\mathrm{IC}_{50}$ value which is a measure of the efficacy of the tested material.

With this background, the present research intends to test the nanotoxic effects of AgNPs synthesized using the leaf extract of R. apiculata. This intention is the basis for recognizing the therapeutic index of such particles in normal and malignant cell lines for applications at the nanoscale.
According to the knowledge of the authors, this is the firstever international report to optimize the synthesis of AgNPs using response surface methodology (RSM) and to identify the therapeutic index of mangrove tree leaf-derived AgNPs towards HeLa cells in comparison with HEK-293 cells.

\section{Materials and Methods Synthesis of AgNPs}

One gram of $R$. apiculata leaf powder was dissolved in $100 \mathrm{~mL}$ of Millipore water and incubated at $60{ }^{\circ} \mathrm{C}$ for 5 minutes. Five millilitres of the resultant aqueous extract was mixed with $95 \mathrm{~mL}$ of $1 \mathrm{mM}$ aqueous $\mathrm{AgNO}_{3}$ solution and incubated at varying temperatures from $30{ }^{\circ} \mathrm{C}$ to $95{ }^{\circ} \mathrm{C}$. After visual observation of colour change to brown, the hydrosol was centrifuged at $10,000 \mathrm{rpm}$ for 20 minutes at $4{ }^{\circ} \mathrm{C}$ to derive a pellet that contains AgNPs. The synthesis is performed similarly to the method followed by Song and Kim et al with slight modifications. ${ }^{26}$

\section{Characterization of AgNPs}

The synthesized nanoparticles were characterized by our previous reports using spectroscopic techniques such as ultraviolet-visible, X-ray photoelectron and fouriertransform infrared spectroscopy. Transmission (TEM) and scanning (SEM) electron microscopes were used to determine the morphology of AgNPs. Techniques such as energy dispersive X-ray analysis and inductively coupled plasma-optical emission spectrometry (ICP-OES) were used for establishing the elemental composition. Zeta potential, particle size and polydispersity index were determined using dynamic light scattering. ${ }^{27-30}$ The nanoparticles were further characterized by X-ray diffraction (XRD) analysis using PANalytical $X^{\prime}$ Pert $^{3}$ Powder instrument (Malvern Panalytical Inc., Westborough, MA, USA) in this study. SEM and TEM observations were made at different sites and magnifications in comparison to our published report and presented here.

\section{Cytotoxicity of AgNPs}

The cell lines were purchased from National Centre for Cell Science (NCCS), Pune and used for the study. To validate the use of AgNPs for biomedical applications, toxicity assessment against normal HEK-293 and human cervical cancer cell line HeLa was performed, in the present report, in triplicate. Minimum Essential medium-Eagle supplemented with $10 \%$ fetal bovine serum was used for maintaining the cells at $37{ }^{\circ} \mathrm{C}, 5 \% \mathrm{CO}_{2}, 95 \%$ air and $100 \%$ relative 
humidity. One hundred microlitres of the cell suspension was implanted at a concentration of 10,000 cells in every well and incubated for 24 hours. After incubation, the medium seeded with HEK-293 and HeLa cells were treated with different concentrations of the AgNPs-containing hydrosol ( 0.005 to $2.5 \mu \mathrm{L} / \mathrm{mL})$. After 48 hours of treatment, the cells were washed and the rate of cellular proliferation was determined by observation through an inverted microscope. 3-(4,5-dimethylthiazol-2-yl)-2,5-diphenyltetrazolium bromide (MTT) assay was performed and the percentage of cell inhibition was calculated using the following formula:

$\%$ cell inhibition $=100-\mathrm{Abs}(\mathrm{Test}) / \mathrm{Abs}(\mathrm{Control})$ x 100

Cell viability was plotted in relation to logarithmic concentrations of AgNPs and $\mathrm{IC}_{50}$ was determined using GraphPad Prism software (Version 6.01). ${ }^{31,32}$

\section{Data Analysis}

The Central composite design (CCD) based on RSM was applied for the study. The optimum responses were calculated and the Design-Expert software Version 13 (State-Ease Inc., Minneapolis, MN, USA) was used to interpret the results.

\section{Results and Discussion}

Regression analysis is a widely used statistical technique that employs models such as Langmuir. ${ }^{33-35}$ According to the statistical analysis, the Model $F$-value of 3.18 indicates that the model is significant. The $F$-value indicates that there is an extremely low chance (4.28\%) of this phenomenon occurring as a resultant of noise. The Adeq Precision indicates a signal-to-noise ratio of 8.067. A ratio larger than 4 is usually desired. Therefore, the ratio observed in this study seems adequate to navigate the design space. ${ }^{36,37}$ The $\mathrm{R}^{2}$ value near to 1 determines an ideal connection between the mean and the data. ${ }^{38}$ The $\mathrm{R}^{2}$ value obtained in this study (0.7413) correlates to this connection better. The mean of surface plasmon resonance (SPR) of AgNPs in this study (429.45 nm) was in the range of 410 to $450 \mathrm{~nm}$ indicating spherical nanoparticles of sizes less than $100 \mathrm{~nm}$ that are effectively cytotoxic in comparison to microparticles (Figure 1, Tables 1 and 2). ${ }^{39,40}$
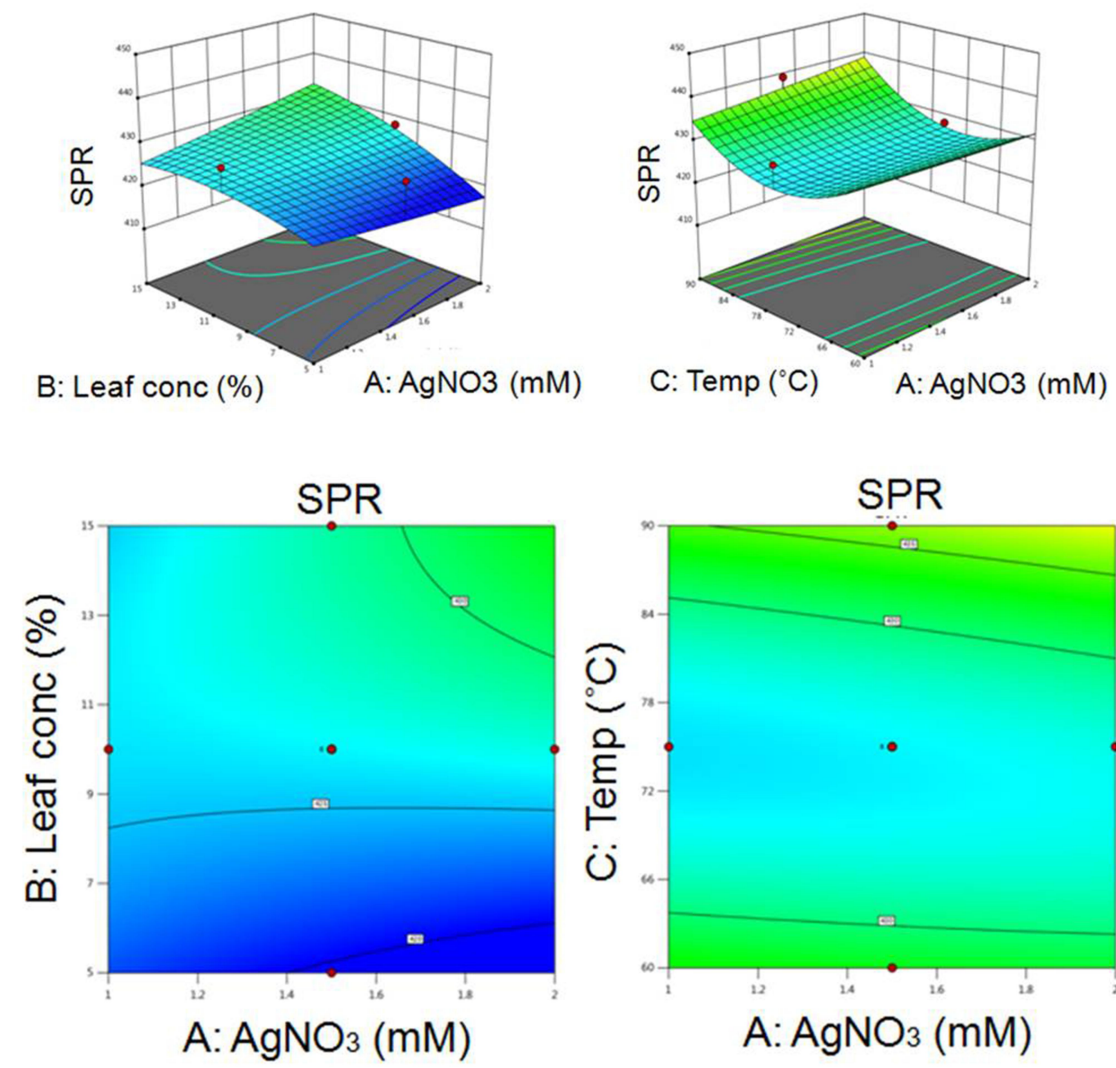

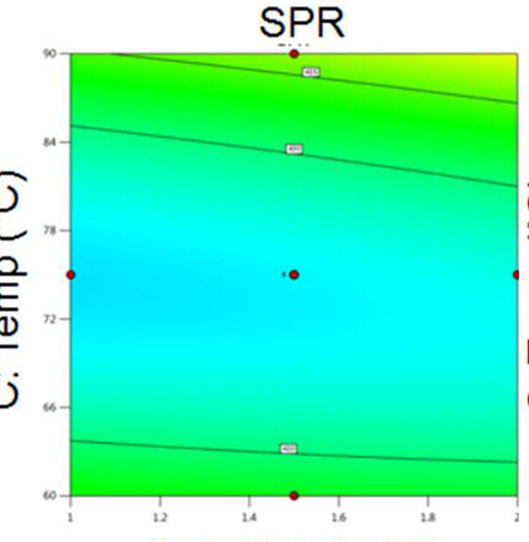

$\mathrm{A}: \mathrm{AgNO}_{3}(\mathrm{mM})$
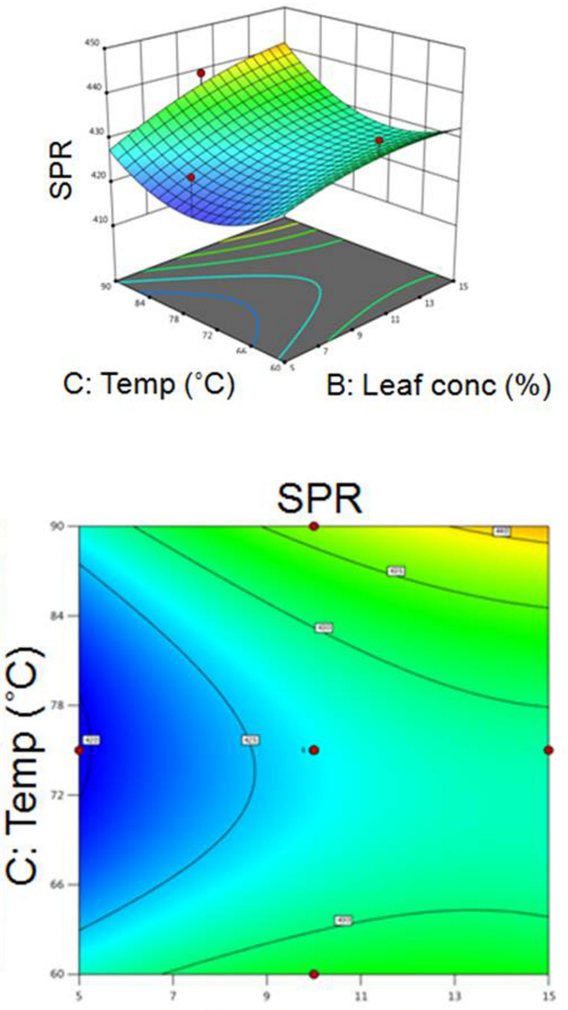

B: Leaf conc (\%)

Figure I Response surface plots and contour plots for the synthesized AgNPs. 
Table I ANOVA, Lack of Fit Test and the Significance of Response Surface Model for the Synthesized AgNPs Using CCD

\begin{tabular}{|c|c|c|c|c|c|c|}
\hline Source & Sum of Squares & df & Mean Square & F-value & $p$-value & \\
\hline Model & 656.59 & 9 & 72.95 & 3.18 & 0.0428 & Significant \\
\hline $\mathrm{A}-\mathrm{AgNO}_{3}(\mathrm{mM})$ & 4.69 & I & 4.69 & 0.2047 & 0.6606 & \\
\hline B-Leaf conc (\%) & 215.57 & I & 215.57 & 9.41 & 0.0119 & \\
\hline $\mathrm{C}-\mathrm{Temp}(\circ \mathrm{C})$ & 45.84 & I & 45.84 & 2.00 & 0.1877 & \\
\hline$A B$ & 70.45 & I & 70.45 & 3.07 & 0.1101 & \\
\hline$A C$ & 18.42 & I & 18.42 & 0.8038 & 0.3910 & \\
\hline BC & 44.94 & I & 44.94 & 1.96 & 0.1917 & \\
\hline A2 & 0.0799 & I & 0.0799 & 0.0035 & $0.954 I$ & \\
\hline B2 & 13.18 & I & 13.18 & 0.5752 & 0.4657 & \\
\hline $\mathrm{C} 2$ & 183.58 & I & 183.58 & 8.01 & 0.0178 & \\
\hline Residual & 229.19 & 10 & 22.92 & & & \\
\hline Lack of Fit & 229.19 & 5 & 45.84 & & & \\
\hline Pure Error & 0.0000 & 5 & 0.0000 & & & \\
\hline Cor Total & 885.78 & 19 & & & & \\
\hline
\end{tabular}

Table 2 Regression Analysis for the Synthesized AgNPs Using CCD

\begin{tabular}{|l|l|l|l|}
\hline Std. Dev. & $\mathbf{4 . 7 9}$ & $\mathbf{R}^{\mathbf{2}}$ & $\mathbf{0 . 7 4 1 3}$ \\
\hline $\begin{array}{l}\text { Mean } \\
\text { C.V. \% }\end{array}$ & 429.45 & $\begin{array}{l}\text { Adjusted } \mathbf{R}^{2} \\
\text { I.II }\end{array}$ & $\begin{array}{l}0.5084 \\
\text { Predicted } \mathbf{R}^{2}\end{array}$ \\
\hline \multicolumn{2}{|l}{} & Adeq Precision & 8.0669 \\
\hline
\end{tabular}

The examination of the structure and crystalline size of the biosynthesized AgNPs was performed using XRD. The pattern indicates diffraction peaks at $(2 \Theta) 32.19^{\circ}, 38.07^{\circ}$, $44.25^{\circ}, 64.43^{\circ}$ and $77.38^{\circ}$. The peaks could be allocated to the (122), (111), (200), (220), and (311) typical planes of face-centered, cubic, and crystalline silver synthesized using green methods (JCPDS file number: 04-0783). The average crystalline size of the AgNPs was calculated using the Debye-Scherrer's equation: $\mathrm{D}=\mathrm{K} \lambda / \beta \cos \theta . \mathrm{K}$ is equivalent to 0.94 , whereas, $\lambda$ is equivalent to 1.54178 . $\beta$ is the line broadening in radians and $\theta$ is the Bragg's angle. According to Bragg's reflection, the estimated average size of the particles was $31.12 \mathrm{~nm}$. The broadening of Bragg's peaks positioned specifies the formation of smaller sized nanoparticles. The unassigned peaks could be correlated to the existence of phytoconstituents ${ }^{41-44}$ (Figure 2). SEM and TEM are electron microscopic techniques used to study the morphology of nanomaterials at various magnifications. ${ }^{45,46}$ The representative images are presented in Figure 3A-D.

Chemotherapeutic drugs lack the capacity to segregate normal forms from cells that are malignant. ${ }^{47}$ Hence, particles are being fabricated at the nano-regime

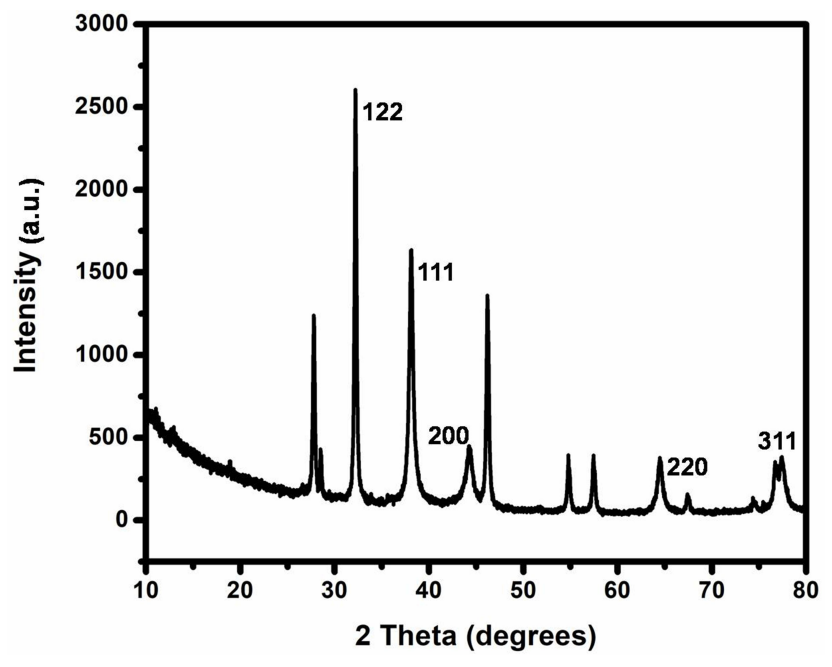

Figure 2 XRD pattern of the synthesized nanoparticles.

to specifically target cancer cells with limited toxicity. Such medical systems that can deter the harmful aftereffects of conventional therapeutic methods are being approved for clinical practice recently. These nanoparticles can enter the tumor microenvironment efficiently and inhibit the cancer cells with the ability to metastasize, from spreading to other sites. ${ }^{48-51}$ Therapeutic index is the measurement or comparison of the ratio of inhibition of normal and cancer cells by any medication. This can lead to the identification of a safety window intended for the treatment of neoplasms. ${ }^{52}$ Consequently, assessment of toxicity on various types of cells is a critical point to warrant the safety of such nanocarriers. ${ }^{53,54}$ Toxicity associated with kidneys is usually tested to identify a drug as they determine the 
A

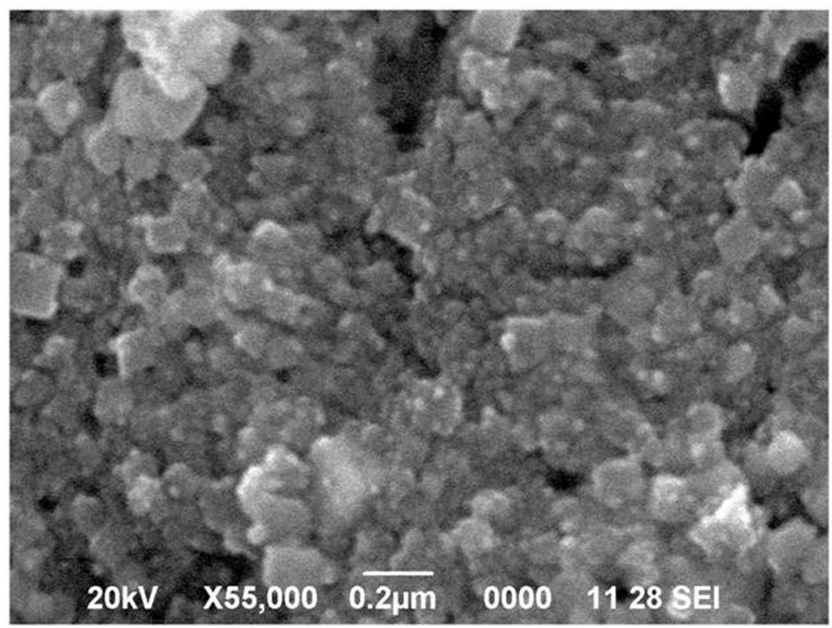

C

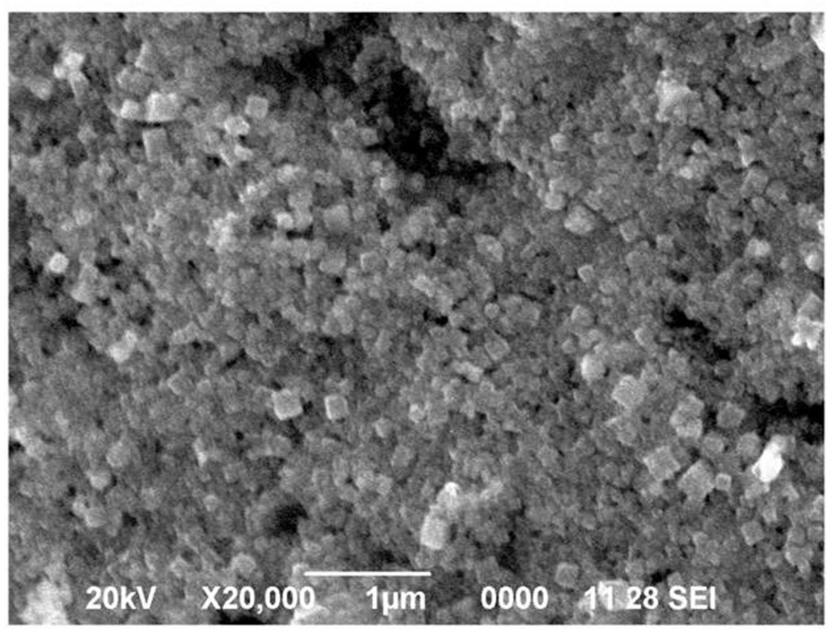

B

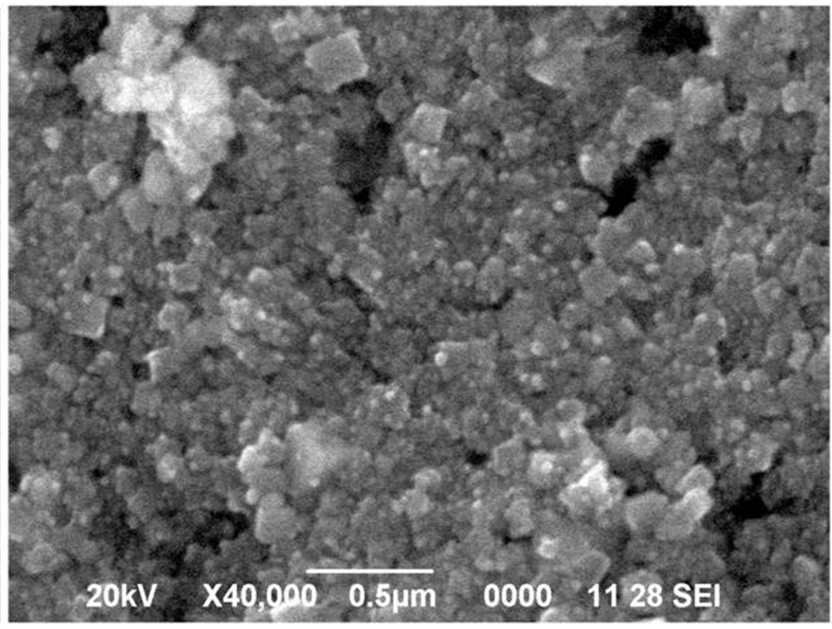

D

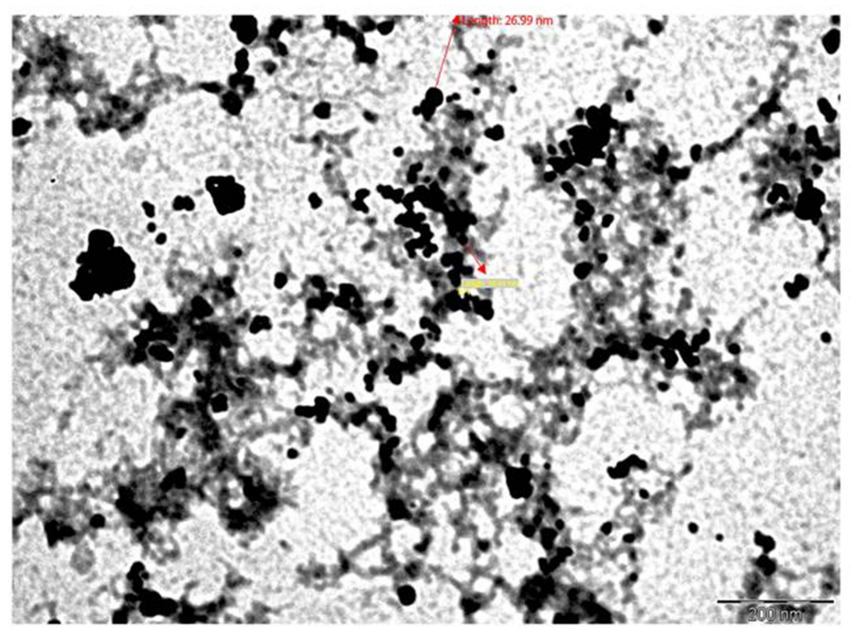

Figure 3 Electron microscopic images of the synthesized AgNPs (A) SEM image taken at $0.2 \mu \mathrm{m}$ (B) SEM image taken at $0.5 \mu \mathrm{m}$ (C) SEM image taken at I $\mu$ m (D) TEM image taken at $200 \mathrm{~nm}$.

homeostasis of the body. ${ }^{55}$ Assessment of toxicity to kidneys is critical in clinical practice. ${ }^{56}$ Therefore, HEK-293 cells were chosen for this study with regard to the identification of nanotoxicity.

AgNPs are renowned for their biomedical applications. $^{57}$ Yet, extensive exposure to AgNPs can cause systemic nanotoxic effects including argyria in humans and intensify the hostile effects towards his environment. ${ }^{58-60}$ Supportive of the aforementioned properties, AgNPs are known to be cytotoxic and genotoxic towards normal cells like HEK-293. Although its origin is still unclear, this normal cell line is used in various biological experiments. The purpose of these trials is to identify the toxicity profile and therapeutic effects with an intention of screening a drug. ${ }^{61-63}$ Therefore, we analysed the cytotoxicity of AgNPs on normal HEK-293 and HeLa cells, in order to indicate its therapeutic window. As an initial analysis, microscopic observations indicated the annihilating effect of AgNPs towards HEK-293 and HeLa cells (Figure 4A and B).

Nanotoxicity of AgNPs is dependent on quite a lot of characteristics such as size, surface, shape, agglomeration, dose and route of administration. Dose determination of an anticancer drug is very critical and foremost for formulating therapeutic strategies. This is due to the fact that an increased dose can cause a decline in the antitumor effect and an upsurge in unintended toxicity. Observations from cytotoxicity experiments indicate that $0.4 \mu \mathrm{g} / \mathrm{mL}$ is the minimal $\mathrm{IC}_{50}$ value for AgNPs among cell lines which are considered to be normal. The highest value analysed was $250 \mu \mathrm{g} / \mathrm{mL}$. Twenty-five ppm 
A

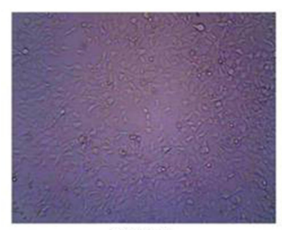

Control

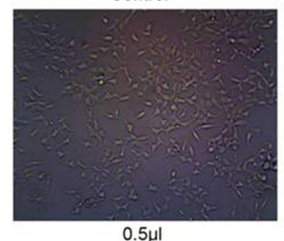

$0.5 \mu \mathrm{l}$

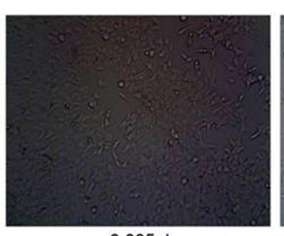

$0.005 \mu \mathrm{l}$

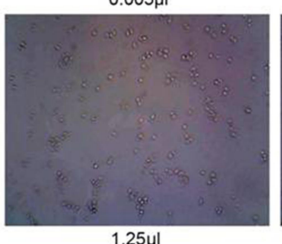

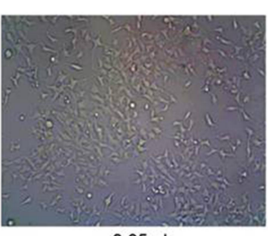

$0.05 \mu \mathrm{l}$

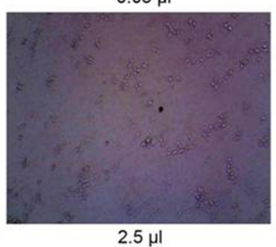

B

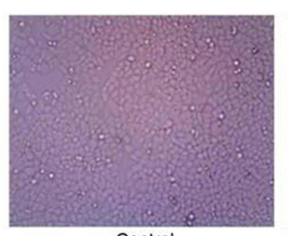

Control

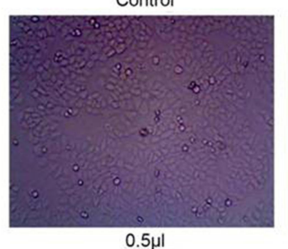

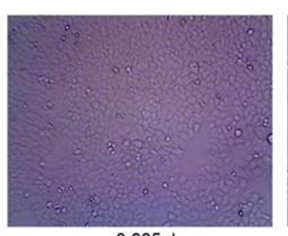

$0.005 \mu l$

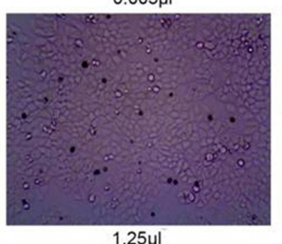

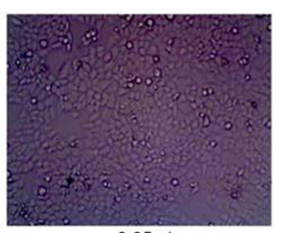

$0.05 \mu \mathrm{l}$

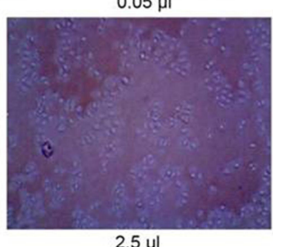

Figure 4 Microscopic observations of the cytotoxic effects of AgNPs on (A) HEK-293 cells (B) HeLa cells.

was the most toxic dose for liver cells. However, genotoxic effects were observed at $0.01-10 \mathrm{mg} / \mathrm{mL}$ in BEAS-2B, a normal lung epithelial cell line. It is interesting to note that the human body can tolerate 0.4 to $27 \mu \mathrm{g}$ of AgNPs per day when consumed through the oral route. Therefore, the nanotoxicity profile can differ based on the dose and the origin of cell lines subjected to a specific toxicity analysis. ${ }^{64-67}$

The results of the present study reveal $100 \%$ cell death of HEK-293 cells at $2.5 \mu \mathrm{L} / \mathrm{mL}$. At the same concentration of $2.5 \mu \mathrm{L} / \mathrm{mL}$ required for $100 \%$ killing of HEK-293 cells, only $75 \%$ cell death was observed among HeLa cells. The percentage of viability is depicted in Figure 5A and $\mathrm{B}$. AgNPs used in this study were less effective against the HeLa cells in comparison to the cytotoxicity exerted by AgNPs on other cancer cell lines like HepG2, NIH-3T3,
PC-12, A-549, HCT116 and SiHa cells. In previous such reports, the $\mathrm{IC}_{50}$ value for $\mathrm{AgNPs}$ on cancerous cell lines did range from 3 to $99 \mathrm{ppm}^{68-71}$ Explicitly, according to existing reports, the $\mathrm{IC}_{50}$ values for AgNPs on HeLa cell lines range from 19 to $51 \mathrm{ppm}^{72-74}$

In the current study, $\mathrm{IC}_{50}$ value for AgNPs on HeLa cells was $1.98 \mu \mathrm{L} / \mathrm{mL}$ (1980 ppm). The concentration of AgNPs in the hydrosol was equivalent to $38.629 \mathrm{ng}$, as per ICP-OES analysis $(19.51 \mu \mathrm{g} / \mathrm{mL})$. The $\mathrm{IC}_{50}$ value for the hydrosol against HEK-293 cells was $0.622 \mu \mathrm{L} / \mathrm{mL}$ (622 ppm). The concentration of AgNPs in $0.622 \mu \mathrm{L}$ of the hydrosol was equivalent to $12.135 \mathrm{ng}$. The $\mathrm{IC}_{50}$ values determine that the AgNPs were three-fold toxic towards HEK-293 cells in comparison to toxicity exerted on HeLa cells. Therefore, based on the $\mathrm{IC}_{50}$ value, this study determines that AgNPs
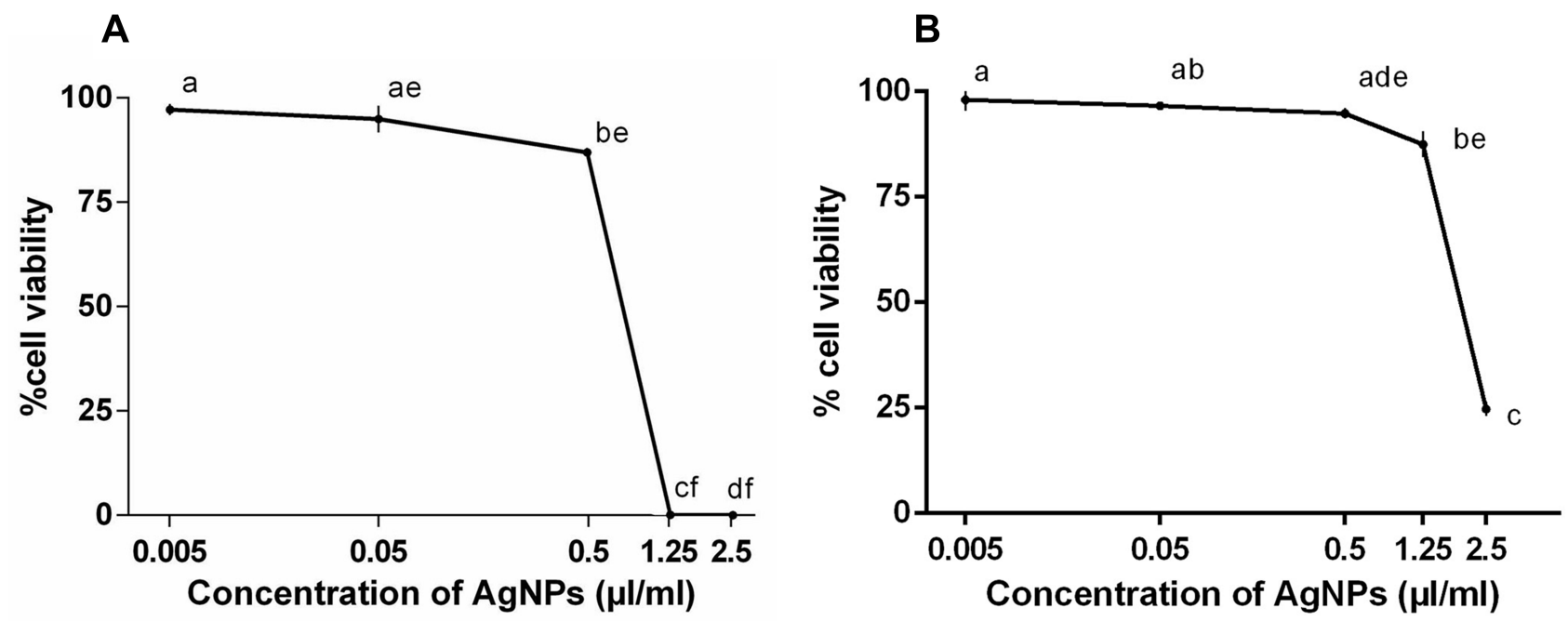

Figure 5 Cytotoxicity of AgNPs on (A) HEK-293 cells (B) HeLa cells. Results were expressed as Mean \pm SEM $(n=3)$ and statistically analysed using one-way ANOVA along with Tukey's post hoc test of significance; different alphabets denote significant difference $(p<0.05)$. 
synthesized using $R$. apiculata were more toxic towards HEK-293 cells in comparison to HeLa cells.

A general expectancy in screening an anticancer drug is to sensitize and destroy the cancer cells rather than the normal cells. ${ }^{75}$ The mechanism of cytotoxicity of nanoparticles is dependent on mechanisms that involve (i) an increase in calcium levels, (ii) genotoxic effects that lead to cell cycle arrest at $\mathrm{G}_{2} / \mathrm{M}$ phase, and (iii) ROS, JNK signaling and mitochondria-dependent apoptosis. ${ }^{76}$ To conclude, the therapeutic index is low for the metastatic HeLa cells, in comparison to the normal cells (HEK-293), as analysed through the present report.

\section{Conclusion}

Conferring to the results of the present study and the supportive conclusions of previously published reports, the AgNPs synthesized using $R$. apiculata could be considered to be nanotoxic against HEK-293 cells while comparing the $\mathrm{IC}_{50}$ values with those of $\mathrm{HeLa}$ cells. The cell inhibiting effects were dependent on the dose used. The AgNPs were less effective against HeLa cells in comparison to HEK-293 cells. Therefore, this study identified that the therapeutic index for HeLa cells is poor and the therapeutic window is not extensive. The nanotoxic effects emerge more towards HEK-293 cells. Although HEK-293 and HeLa cells are of various origins, the work was based on the ideology for future analysis of the systemic toxicity of AgNPs. This means that the AgNPs intended for the therapy of cervical cancer cell model HeLa was toxic towards the normal cell line HEK-293 of the renal system. Further comparative nanotoxicity analysis and mechanistic studies on such toxic effects may provide an insight into the use of these AgNPs for applications in cancer nanomedicine.

\section{Acknowledgments}

We thank Nanome Consulting for the technology transfer of nanoparticle synthesis.

\section{Disclosure}

The authors report no conflicts of interest in this work.

\section{References}

1. Salem SS, Fouda A. Green synthesis of metallic nanoparticles and their prospective biotechnological applications: an overview. Biol Trace Elem Res. 2020.

2. Iqbal P, Preece JA, Mendes PM. Nanotechnology: the "Top-Down" and "Bottom-Up" Approaches. In: Supramolecular Chemistry: From Molecules to Nanomaterials. 2012.
3. Sathishkumar RS, Sundaramanickam A, Srinath R, et al. Green synthesis of silver nanoparticles by bloom forming marine microalgae Trichodesmium erythraeum and its applications in antioxidant, drug-resistant bacteria, and cytotoxicity activity. J Saudi Chem Soc. 2019;23:1180-1191. doi:10.1016/j.jscs.2019.07.008

4. Algebaly AS, Mohammed AE, Abutaha N, Elobeid MM. Biogenic synthesis of silver nanoparticles: antibacterial and cytotoxic potential. Saudi J Biol Sci. 2020;27:1340-1351. doi:10.1016/j. sjbs.2019.12.014

5. Hemlata MPR, Singh AP, Tejavath KK. Biosynthesis of silver nanoparticles using cucumis prophetarum aqueous leaf extract and their antibacterial and antiproliferative activity against cancer cell lines. ACS Omega. 2020;5:5520-5528. doi:10.1021/acsomega.0c00155

6. Huang H, Shan K, Liu J, et al. Synthesis, optimization and characterization of silver nanoparticles using the catkin extract of piper longum for bactericidal effect against food-borne pathogens via conventional and mathematical approaches. Bioorg Chem. 2020;103:104230. doi:10.1016/j.bioorg.2020.104230

7. Singh J, Dutta T, Kim K-H, Rawat M, Samddar P, Kumar P. 'Green' synthesis of metals and their oxide nanoparticles: applications for environmental remediation. $J$ Nanobiotechnol. 2018;16:84.

8. Mousavi SM, Hashemi SA, Ghasemi Y, et al. Green synthesis of silver nanoparticles toward bio and medical applications: review study. Artif Cells, Nanomed Biotechnol. 2018;46:S855-S72. doi:10.1080/21691401.2018.1517769

9. Singh AV, Laux P, Luch A, et al. Review of emerging concepts in nanotoxicology: opportunities and challenges for safer nanomaterial design. Toxicol Mech Methods. 2019;29:378-387. doi:10.1080/ 15376516.2019.1566425

10. Calderón-Jiménez B, Johnson ME, Montoro Bustos AR, Murphy KE, Winchester MR, Vega Baudrit JR. Silver nanoparticles: technological advances, societal impacts, and metrological challenges. Front Chem. 2017;5:6.

11. McClements DJ, Xiao H. Is nano safe in foods? Establishing the factors impacting the gastrointestinal fate and toxicity of organic and inorganic food-grade nanoparticles. Npj Science of Food. 2017;1:6. doi:10.1038/s41538-017-0005-1

12. Lee SH, Jun B-H. Silver nanoparticles: synthesis and application for nanomedicine. Int J Mol Sci. 2019;20:865. doi:10.3390/ijms20040 865

13. Stensberg MC, Wei Q, McLamore ES, Porterfield DM, Wei A, Sepúlveda MS. Toxicological studies on silver nanoparticles: challenges and opportunities in assessment, monitoring and imaging. Nanomedicine (London, England). 2011;6:879-898. doi:10.2217/ nnm. 11.78

14. Ferdous Z, Nemmar A. Health impact of silver nanoparticles: a review of the biodistribution and toxicity following various routes of exposure. Int J Mol Sci. 2020;21:2375. doi:10.3390/ijms21072375

15. Yang Y, Qin Z, Zeng W, et al. Toxicity assessment of nanoparticles in various systems and organs. Nanotechnol Rev. 2017;6:279-289. doi:10.1515/ntrev-2016-0047

16. Chen $\mathrm{L}, \mathrm{Wu} \mathrm{M}$, Jiang $\mathrm{S}$, et al. Skin toxicity assessment of silver nanoparticles in a 3D epidermal model compared to 2D keratinocytes. Int $J$ Nanomedicine. 2019;14:9707. doi:10.2147/IJN. S225451

17. Kavsan VM, Iershov AV, Balynska OV. Immortalized cells and one oncogene in malignant transformation: old insights on new explanation. BMC Cell Biol. 2011;12:23. doi:10.1186/1471-2121$12-23$

18. Sooklert K, Chattong S, Manotham K, et al. Cytoprotective effect of glutaraldehyde erythropoietin on HEK293 kidney cells after silver nanoparticle exposure. Int $J$ Nanomedicine. 2016;11:597. doi:10.21 47/IJN.S95654

19. Peng H, Zhang X, Wei Y, et al. Cytotoxicity of silver nanoparticles in human embryonic stem cell-derived fibroblasts and an L-929 cell line. J Nanomater. 2012;2012:160145. doi:10.1155/2012/160145 
20. Sahu SC, Hayes AW. Toxicity of nanomaterials found in human environment: a literature review. Toxicol Res Appl. 2017;1:2397 847317726352. doi:10.1177/2397847317726352

21. Mirabelli P, Coppola L, Salvatore M. Cancer cell lines are useful model systems for medical research. Cancers (Basel). 2019;11:1098. doi:10.3390/cancers 11081098

22. Bahuguna A, Khan I, Bajpai VK, Kang SC. MTT assay to evaluate the cytotoxic potential of a drug. Bangladesh J Pharmacol. 2017;12: Online: Apr. doi:10.3329/bjp.v12i2.30892

23. Aykul S, Martinez-Hackert E. Determination of half-maximal inhibitory concentration using biosensor-based protein interaction analysis. Anal Biochem. 2016;508:97-103. doi:10.1016/j.ab.2016.06.025

24. Yuan Y-G, Zhang S, Hwang J-Y, Kong I-K. Silver nanoparticles potentiates cytotoxicity and apoptotic potential of camptothecin in human cervical cancer cells. Oxid Med Cell Longev. 2018;20 18:6121328. doi:10.1155/2018/6121328

25. Ratan ZA, Haidere MF, Nurunnabi M, et al. Green chemistry synthesis of silver nanoparticles and their potential anticancer effects. Cancers (Basel). 2020;12:855. doi:10.3390/cancers12040855

26. Song JY, Kim BS. Rapid biological synthesis of silver nanoparticles using plant leaf extracts. Bioprocess Biosyst Eng. 2009;32:79-84. doi:10.1007/s00449-008-0224-6

27. Antony JJ, Sivalingam P, Siva D, et al. Comparative evaluation of antibacterial activity of silver nanoparticles synthesized using Rhizophora apiculata and glucose. Colloids Surf B Biointerfaces. 2011;88:134-140. doi:10.1016/j.colsurfb.2011.06.022

28. Jacob JA, Shanmugam A. Silver nanoparticles provoke apoptosis of Dalton's ascites lymphoma in vivo by mitochondria dependent and independent pathways. Colloids Surf B Biointerfaces. 2015;136:1011-1016. doi:10.1016/j.colsurfb.2015.11.004

29. Zhang H, Jacob JA, Jiang Z, et al. Hepatoprotective effect of silver nanoparticles synthesized using aqueous leaf extract of Rhizophora apiculata. Int J Nanomedicine. 2019;14:3517-3524. doi:10.2147/IJN. S198895

30. Wen X, Wang Q, Dai T, et al. Identification of possible reductants in the aqueous leaf extract of mangrove plant Rhizophora apiculata for the fabrication and cytotoxicity of silver nanoparticles against human osteosarcoma MG-63 cells. Mater Sci Eng C. 2020;116:111252. doi:10.1016/j.msec.2020.111252

31. Mosmann T. Rapid colorimetric assay for cellular growth and survival: application to proliferation and cytotoxicity assays. J Immunol Methods. 1983;65:55-63. doi:10.1016/0022-1759(83)90303-4

32. Monks A, Scudiero D, Skehan P, et al. Feasibility of a high-flux anticancer drug screen using a diverse panel of cultured human tumor cell lines. J Natl Cancer Inst. 1991;83:757-766. doi:10.1093/jnci/ 83.11 .757

33. Kumari K, Yadav S. Linear regression analysis study. J Pract Cardiovasc Sci. 2018;4:33. doi:10.4103/jpcs.jpcs_8_18

34. Marković DD, Lekić BM, Rajaković-Ognjanović VN, Onjia AE, Rajaković LV, New A. Approach in regression analysis for modeling adsorption isotherms. Sci World J. 2014;2014:930879. doi:10.1155/ 2014/930879

35. Rashtbari Y, Arfaeinia H, Ahmadi S, et al. Potential of using green adsorbent of humic acid removal from aqueous solutions: equilibrium, kinetics, thermodynamic and regeneration studies. Int J Environ Anal Chem. 2020:1-18. doi:10.1080/03067319.2020.1796993

36. Ahmadi S, Mohammadi L, Rahdar A, et al. Acid dye removal from aqueous solution by using neodymium(III) oxide nanoadsorbents. Nanomaterials. 2020;10:556. doi:10.3390/nano10030556

37. Sandhya M, Rajkumar K, Burgula S. Efficient eco-friendly approach towards bimetallic nanoparticles synthesis and characterization using Exiguobacterium aestuarii by statistical optimization. Green Chem Lett Rev. 2019;12:420-434. doi:10.1080/17518253.2019.1687762

38. Saunders LJ, Russell RA, Crabb DP. The coefficient of determination: what determines a useful R2 statistic? Invest Ophthalmol Vis Sci. 2012;53:6830-6832. doi:10.1167/iovs.12-10598
39. Suriyakalaa U, Antony JJ, Suganya S, et al. Hepatocurative activity of biosynthesized silver nanoparticles fabricated using Andrographis paniculata. Colloids Surf B Biointerfaces. 2013;102:189-194. doi:10.1016/j.colsurfb.2012.06.039

40. Sahu D, Kannan G, Tailang M, Vijayaraghavan R. In vitro cytotoxicity of nanoparticles: a comparison between particle size and cell type. J Nanosci. 2016;2016:1-9. doi:10.1155/2016/4023852

41. Jemal K, Sandeep B, Pola S. Synthesis, characterization, and evaluation of the antibacterial activity of allophylus serratus leaf and leaf derived callus extracts mediated silver nanoparticles. J Nanomater. 2017;2017:1-11. doi:10.1155/2017/4213275

42. Anandalakshmi K, Venugobal J, Ramasamy V. Characterization of silver nanoparticles by green synthesis method using Pedalium murex leaf extract and their antibacterial activity. Appl Nanosci. 2016;6:399-408. doi:10.1007/s13204-015-0449-z

43. Sree GS, Botsa SM, Reddy BJM, Ranjitha KVB. Enhanced UVVisible triggered photocatalytic degradation of Brilliant green by reduced graphene oxide based $\mathrm{NiO}$ and $\mathrm{CuO}$ ternary nanocomposite and their antimicrobial activity. Arab J Chem. 2020;13:5137-5150. doi:10.1016/j.arabjc.2020.02.012

44. Botsa SM, Naidu GP, Ravichandra M, Rani SJ, Anjaneyulu RB, Ramana CV. Flower like SnO2-Fe2O3-rGO ternary composite as highly efficient visible light induced photocatalyst for the degradation of organic pollutants from contaminated water. J Mater Res Technol. 2020;9:12461-12472. doi:10.1016/j.jmrt.2020.08.087

45. Zhang XF, Liu ZG, Shen W, Gurunathan S. Silver nanoparticles: synthesis, characterization, properties, applications, and therapeutic approaches. Int J Mol Sci. 2016;17:1534. doi:10.3390/ijms17091534

46. Su D. Advanced electron microscopy characterization of nanomaterials for catalysis. Green Energy Environ. 2017;2:70-83. doi:10.1016/ j.gee.2017.02.001

47. Yuan M, Huang -L-L, Chen J-H, Wu J, Xu Q. The emerging treatment landscape of targeted therapy in non-small-cell lung cancer. Signal Transduct Target Ther. 2019;4:61. doi:10.1038/s41392-0190099-9

48. Parasuraman S. Toxicological screening. J Pharmacol Pharmacother. 2011;2:74-79. doi:10.4103/0976-500X.81895

49. Sutradhar KB, Amin ML. Nanotechnology in cancer drug delivery and selective targeting. ISRN Nanotechnol. 2014;2014:939378. doi:10.1155/2014/939378

50. Miao L, Huang L. Exploring the tumor microenvironment with nanoparticles. Cancer Treat Res. 2015;166:193-226.

51. Fernandes C, Suares D, Yergeri MC. Tumor microenvironment targeted nanotherapy. Front Pharmacol. 2018;9.

52. Deepa PR, Vandhana S, Jayanthi U, Krishnakumar S. Therapeutic and toxicologic evaluation of anti-lipogenic agents in cancer cells compared with non-neoplastic cells. Basic Clin Pharmacol Toxicol. 2012;110:494-503. doi:10.1111/j.1742-7843.2011.00844.x

53. Li W, Zhou J, Xu Y. Study of the in vitro cytotoxicity testing of medical devices. Biomed Rep. 2015;3:617-620. doi:10.3892/ br.2015.481

54. Patra JK, Das G, Fraceto LF, et al. Nano based drug delivery systems: recent developments and future prospects. $J$ Nanobiotechnol. 2018;16:71.

55. Kim SY, Moon A. Drug-induced nephrotoxicity and its biomarkers. Biomol Ther (Seoul). 2012;20:268-272. doi:10.4062/biomolther.20 12.20.3.268

56. Basile DP, Anderson MD, Sutton TA. Pathophysiology of acute kidney injury. Compr Physiol. 2012;2:1303-1353. doi:10.1002/cphy.c110041

57. A-C B, Gherasim O, Grumezescu AM, Mogoantă L, Ficai A, Andronescu E. Biomedical applications of silver nanoparticles: an up-to-date overview. Nanomaterials (Basel). 2018;8:681. doi:10. 3390/nano8090681

58. Antony JJ, Sivalingam P, Chen B. Toxicological effects of silver nanoparticles. Environ Toxicol Pharmacol. 2015;40:729-732. doi:10.1016/j.etap.2015.09.003 
59. Paknejadi M, Bayat M, Salimi M, Razavilar V. Concentration-and time-dependent cytotoxicity of silver nanoparticles on normal human skin fibroblast cell line. Iran Red Crescent Med J. 2018;20.

60. Murphy M, Ting K, Zhang X, Soo C, Zheng Z. Current development of silver nanoparticle preparation, investigation, and application in the field of medicine. J Nanomater. 2015;2015:696918. doi:10.1155/ 2015/696918

61. Jiang X, Lu C, Tang M, et al. Nanotoxicity of silver nanoparticles on HEK293T cells: a combined study using biomechanical and biological techniques. ACS Omega. 2018;3:6770-6778. doi:10.1021/acsomega. $8 \mathrm{~b} 00608$

62. Bethu MS, Netala VR, Domdi L, Tartte V, Janapala VR. Potential anticancer activity of biogenic silver nanoparticles using leaf extract of Rhynchosia suaveolens: an insight into the mechanism. Artif Cells, Nanomed Biotechnol. 2018;46:104-114. doi:10.1080/21691401.20 17.1414824

63. Stepanenko AA, Dmitrenko VV. HEK293 in cell biology and cancer research: phenotype, karyotype, tumorigenicity, and stress-induced genome-phenotype evolution. Gene. 2015;569:182-190. doi:10.10 16/j.gene.2015.05.065

64. Yildirimer L, Thanh NTK, Loizidou M, Seifalian AM. Toxicology and clinical potential of nanoparticles. Nano Today. 2011;6:585-607. doi:10.1016/j.nantod.2011.10.001

65. Budama-Kilinc Y, Cakir-Koc R, Zorlu T, et al. Assessment of nanotoxicity and safety profiles of silver nanoparticles. In: Khan M, editor. Silver Nanoparticles-Fabrication, Characterization and Applications. London: Intechopen; 2018:185.

66. Akter M, Sikder MT, Rahman MM, et al. A systematic review on silver nanoparticles-induced cytotoxicity: physicochemical properties and perspectives. $J A d v$ Res. 2018;9:1-16. doi:10.1016/j.jare.2017. 10.008

67. Gurney H. How to calculate the dose of chemotherapy. Br J Cancer. 2002;86:1297-1302. doi:10.1038/sj.bjc.6600139
68. Sambale F, Wagner S, Stahl F, Khaydarov R, Scheper T, Bahnemann D. Investigations of the toxic effect of silver nanoparticles on mammalian cell lines. $J$ Nanomater. 2015;2015:1-9. doi: $10.1155 / 2015 / 136765$

69. Mishra A, Mehdi SJ, Irshad M, et al. Effect of biologically synthesized silver nanoparticles on human cancer cells. Sci Adv Mat. 2012;4:1200-1206. doi:10.1166/sam.2012.1414

70. Sufyani A, Moslah N, Hussien NA, Hawsawi YM. Characterization and anticancer potential of silver nanoparticles biosynthesized from olea chrysophylla and lavandula dentata leaf extracts on HCT116 colon cancer cells. J Nanomater. 2019;2019:1-9. doi:10.1155/2019/7361695

71. Aziz N, Faraz M, Sherwani MA, Fatma T, Prasad R. Illuminating the anticancerous efficacy of a new fungal chassis for silver nanoparticle synthesis. Front Chem. 2019;7:65. doi:10.3389/fchem.2019.00065

72. Chanthini AB, Balasubramani G, Ramkumar R, et al. Structural characterization, antioxidant and in vitro cytotoxic properties of seagrass, Cymodocea serrulata (R. Br.) Asch. \& Magnus mediated silver nanoparticles. J Photochem Photobiol B. 2015;153:145-152. doi:10.1016/j.jphotobiol.2015.09.014

73. Jeyaraj M, Rajesh M, Arun R, et al. An investigation on the cytotoxicity and caspase-mediated apoptotic effect of biologically synthesized silver nanoparticles using Podophyllum hexandrum on human cervical carcinoma cells. Colloids Surf B Biointerfaces. 2013;102:708-717. doi:10.1016/j.colsurfb.2012.09.042

74. Ahmed MJ, Murtaza G, Rashid F, Iqbal J. Eco-friendly green synthesis of silver nanoparticles and their potential applications as antioxidant and anticancer agents. Drug Dev Ind Pharm. 2019;45:1682-1694. doi:10.1080/03639045.2019.1656224

75. Vazquez A. The universe of normal and cancer cell line responses to anticancer treatment: lessons for cancer therapy. Nat Preced. 2011;1.

76. Kumar V, Sharma N, Maitra SS. In vitro and in vivo toxicity assessment of nanoparticles. Int Nano Lett. 2017;7:243-256.
International Journal of Nanomedicine

\section{Publish your work in this journal}

The International Journal of Nanomedicine is an international, peerreviewed journal focusing on the application of nanotechnology in diagnostics, therapeutics, and drug delivery systems throughout the biomedical field. This journal is indexed on PubMed Central, MedLine, CAS, SciSearch ${ }^{\mathbb{R}}$, Current Contents ${ }^{\mathbb{B}} /$ Clinical Medicine, $^{2}$
Journal Citation Reports/Science Edition, EMBase, Scopus and the Elsevier Bibliographic databases. The manuscript management system is completely online and includes a very quick and fair peer-review system, which is all easy to use. Visit http://www.dovepress.com/ testimonials.php to read real quotes from published authors. 